\title{
Future of Avian Genetic Resources Collections: Archives of Evolutionary and Environmental History
}

\section{Citation}

Edwards, Scott V., Sharon Birks, Robb T. Brumfield, and Robert Hanner. 2005. Future of avian genetic resources collections: Archives of evolutionary and environmental history. Auk 122(3): 979-984.

\section{Published Version}

http://dx.doi.org/10.1642/0004-8038(2005)122[0979:FOAGRC]2.0.C0;2

\section{Permanent link}

http://nrs.harvard.edu/urn-3:HUL.InstRepos:2664296

\section{Terms of Use}

This article was downloaded from Harvard University's DASH repository, and is made available under the terms and conditions applicable to Other Posted Material, as set forth at http:// nrs.harvard.edu/urn-3:HUL.InstRepos:dash.current.terms-of-use\#LAA

\section{Share Your Story}

The Harvard community has made this article openly available.

Please share how this access benefits you. Submit a story.

\section{Accessibility}


Union and Oklahoma Biological Survey, Norman, Oklahoma.

Wood, D. S., R. L. Zusi, and M. A. Jenkinson. 1982. World Inventory of Avian Skeletal Specimens, 1982. American Ornithologists' Union and Oklahoma Biological Survey, Norman, Oklahoma.

Zhou, Z., AND F. ZHANG. 2003. Anatomy of the primitive bird Sapeornis chaoyangensis from the Early Cretaceous of Liaoning, China. Canadian Journal of Earth Sciences 40:731-747.

The Auk 122(3):979-984, 2005

(C) The American Ornithologists' Union, 2005. Printed in USA.

Future of Avian Genetic Resources Collections: Archives of Evolutionary and Environmental History. - In the past 30 years, genetic resources collections (GRCs) have shifted position within ornithology, from a novel supplement to traditional voucher collections to a major core source of raw material fueling multiple subdisciplines. The demand for specimens from GRCs now greatly exceeds both the demand for traditional voucher specimens and, in many cases, the resources available to museums to maintain GRCs. The projection for the next decade is ever-increasing use. Here, we present a brief update on modern principles and challenges of collection, storage, organization, use, and dissemination of genetic resources and electronic information associated with such collections, drawing heavily on the experience of building, loaning, and curating the GRC of the Burke Museum at the University of Washington. The Burke Museum was established under the curatorship of Sievert Rohwer in 1986 and is now the second-largest such collection for birds in the United States, after that of Louisiana State University. In addition, we make a number of recommendations for ensuring the long-term sustainability and value of avian GRCs.

Unique challenges for avian genetic resources collections. -There are now several large (5,000-60,0000 individual specimens) avian GRCs in North America, Europe, and Australia, and many other museums and individuals have smaller GRCs. These collections typically consist of frozen tissues (heart, liver, muscle) of birds. In many cases, field and storage practices have changed little since their origin in ornithology in the 1970s and 1980s (Johnson et al. 1984). Because sampling from genetic resources is destructive and nonrenewable without further collecting, there are a number of issues regarding loan policies and reciprocation that are specific to these collections. The fate of GRCs is tied, even more intimately than the fate of voucher collections, to the future of field collecting; whereas traditional GRCs consisting of frozen tissues must eventually be renewed by continued fieldwork, current voucher collections will, in principle, remain intact and valuable without any further fieldwork. Particularly for small to midsize museums with little internal funding for the upkeep of GRCs (such as the Burke Museum), it remains a challenge to provide for the increasing demand on GRCs while at the same time recouping costs for field collecting, curation, and storage of tissues. These collections and others like them face a unique set of challenges: how to balance the activities that build, preserve, and promote use of their collections with an eye toward maintaining optimal use for future researchers.

Genetic resources collections demand little space, but take substantial staff time to organize and are expensive to maintain. Frozen collections need almost constant vigilance even with an alarm system installed (Dessauer et al. 1996). Because they are newer than traditional collections, they usually represent a small $(\leq 35 \%)$ overall proportion of specimens, but are nonetheless heavily used. Loan activity can become a large investment for the host institution: for example, in 2003 the Burke Museum loaned subsamples of $5 \%$ (1,500 tissues) of its collection to researchers at other institutions, with a substantial outlay in both staff time and supplies. At the Burke, the upward trend in activity has been consistent over the past 10 years and shows no sign of diminishing. Because these loans are to individuals at institutions all over the world, they indicate a general increase in demand on tissue collections.

Field collecting and molecular protocols.-Since their inception, avian GRCs have been used primarily in the arena of systematics, including molecular phylogenetics and phylogeography. More recently, common uses have come to include conservation genetics and stable-isotope analysis, in which chemical signatures derived 
from tissues can help determine recent diet or habitat from which the tissue was collected (see Rocque and Winker 2005). In the past 25 years, the uses of avian GRCs have changed dramatically, from protein, DNA hybridization, and RFLP (restriction fragment length polymorphism) studies requiring relatively large amounts of blood or other tissues to polymerase chain reaction (PCR) based DNA sequence and fragment analyses requiring only picogram quantities of DNA (e.g. amplified fragment length polymorphism (AFLP) analysis; Wang et al. 2003). Ironically, because of their exquisite sensitivity even with degraded DNA templates, PCR methods have, in our view, contributed to the decline of meticulcus field collection and archiving practices, because the threshold of quality for PCR methods is often lower than for other molecular biological approaches. Tissue culture methods have the advantage of providing an unlimited supply of genomic material but are labor-intensive to set up and, to our knowledge, have not been adopted by ornithologists as they have been by mammalogists (e.g. the Zoological Society of San Diego's Center for Reproduction of Endangered Species [CRES]).

We conducted an informal survey of five of the major avian GRCs in the United States to determine trends in loan activity and research use. Our findings suggest that $60-70 \%$ of current loans are for phylogenetic studies (i.e. involving one or a few exemplars of different species) and that the vast majority of remaining loans are to researchers studying pcpulation genetics (i.e. many individuals of a single species). Loans for other types of projerts (e.g. stable-isotope analysis, studies in basic: molecular evolution) are currently uncommon. Sadly, researchers using techniques such a: BAC (bacteria artificial chromosome) library construction (which requires very high molecular weight DNA) or microarrays and expressed-sequence-tag (EST) surveys of gene expression (which require intact RNA transcripts) cannot rnake use of most avian GRCs because the DNA and RNA have not been stored appropriately. With this in mind, it is imperative that the method of preservation, both in the field and in the GRC itself, maximize the potential uses o: the tissue, especially as specialized techniques in genomics become more taxonomically widespread (Couzin 2002, Edwards et al. 2005). Fle.sh-freezing fresh tissue in liquid nitrogen, though logistically complicated, still represents the gold standard for preservation of avian tissues in the field (Engstrom et al. 1999). Storage of tissues in lysis buffer (Seutin et al. 1991) has the advantage of not requiring deep freezing and is very effective for isolating high-molecular-weight DNA, but lysing cells makes isolation of RNA or even of purified mitochondrial DNA a problem. Some protocols and storage buffers offer the ability to preserve RNA for PCR assays (Miller and Lambert 2003). However, even nitrogen storage will be inadequate for many molecular protocols if the tissues are left at ambient temperature for hours after the blood sample is obtained or the individual sacrificed. Thus, an appropriate goal for GRCs would be to gather a synoptic collection of one or several RNA-quality samples per species.

Genetic resources collections will undoubtedly play a large role in "DNA barcoding," an initiative whose goal is to genetically characterize many existing museum voucher specimens with a short DNA sequence(s) to facilitate future field identification and species discovery. DNA barcoding is controversial, not only because it is closely linked with the controversial idea that DNA sequences can form the sole basis for taxonomy (DNA taxonomy), but also because of the many well-known theoretical shortcomings of short, single-locus molecular characterizations of biodiversity for purposes of species assignment (Moritz and Cicero 2004). We suggest that curators and users of GRCs scrutinize carefully the claims of DNA barcoding and draw a distinction between the theoretical issues surrounding species designation by DNA and the potential practical benefits to the additional information provided by DNA sequences. By maintaining a utilitarian view of this controversy, genetic resources curators and collections stand to leverage substantial resources if DNA barcoding is conducted on the large scale outlined in some schemes (Stoeckle 2003), and few would deny that even a single DNA sequence attached to a voucher can only increase the information content of that voucher.

Organization and archiving of genetic resources collections.-Most avian GRCs store tissues in cryogenic conditions-either the vapor phase of liquid nitrogen or in electric freezers set at around $-80^{\circ} \mathrm{C}$ (Prindini et al. 2002). The major advantage of liquid-nitrogen systems is that they increase the long-term 
stability of macromolecules and the breadth of uses to which the tissues can eventually be put. However, they often take up more floor space-an important consideration for collections with space limitations. Also, samples are sometimes more difficult to see and access in liquid-nitrogen freezers, and it is more difficult to accommodate samples in nonstandard containers, which may be a problem for collections with very active loan and acquisition programs. It is known that archiving in mechanical freezers maintains materials above the critical preservation temperature for many biomolecules (Franks 1985); this, in conjunction with a frequent lack of backup freezer space, puts many GRCs in jeopardy. Indeed, the past decade has seen the thawing and eventual loss of several large and vital avian GRCs. The storage system chosen for GRCs will vary depending on the use and resources available to the collections. For example, freezers are generally less expensive to operate; when the Burke Museum decided to increase its storage capacity for tissues in the late 1990s, we chose increased freezer space over nitrogen, primarily because it was cheaper to set up and maintain. By contrast, the American Museum of Natural History's Ambrose Monell Collection for Molecular and Microbial Research is housed in an endowed, state-of-the-art storage system based entirely on nitrogen-maintenance costs typically run $\sim \$ 40,000$ per year (R. Desalle pers. comm.). Hopefully, institutions wishing to switch to nitrogen storage can convince those who pay the utility bills for freezers that they can at least partly recoup electrical costs by investing in nitrogen. In either case, tissues are typically kept in uniform-sized $(2 \mathrm{~mL})$ cryovials and organized in boxes and racks for easy retrieval. We expect that, for tracking and mapping purposes, most large GRCs will complement traditional hand-written vial labels with computer-generated labels or bar codes, which are permanent, easier to standardize, and less susceptible to degradation.

Collections are usually organized taxonomically or numerically (by museum or collector number), and taxonomic organization has been recommended elsewhere (Dessauer et al. 1996). The Burke Museum GRC has adopted a numerical organization scheme because we felt it permitted rapid retrieval of tissues and valued that the scheme can be used efficiently by anyone, especially student helpers who may be unfamiliar with specific taxonomies. Organization systems become crucially important as collections grow in size, complexity, and loan activity, and even managers may find themselves caring for tissues from organisms outside their area of taxonomic expertise. Because Burke researchers frequently collect generally rather than for a specific research project, we found that adding new tissues at the end of a number series is substantially easier than threading these tissues one by one among those already installed in numerous boxes. Numerical organization also minimizes the difficulty of incorporating future taxonomic revisions and, because precise location of a given tube is always known, loan processing remains rapid. On the other hand, numerical organization can be a hindrance when sampling multiple samples from a single taxon, which may be distributed over several collectors and accessions throughout one or multiple freezers.

Traditional and digital vouchers for genetic resources collections.-Because of a growing acknowledgment of the importance of voucher specimens for molecular research (Winker et al. 1996, Ruedas et al. 2000), a primary goal for many collections is to have all or most of their samples vouchered with traditional specimens (Thomas 1994). However, for frozen-tissue repositories, this traditional definition of a voucher can become impractical and - for many collection endeavors involving endangered species or in countries where permits to conduct destructive sampling are difficult to obtainhard to implement. Such nonvouchered samples are undeniably valuable, often have substantial associated data, and in most cases are identified correctly to species, yet museums are naturally reluctant to absorb large numbers because of space constraints and lack of vouchers.

In some cases, such samples are associated with field voice recordings or photographs, or both, to increase their reliability. The term "evoucher," coined by Monk and Baker (2001), applies to such documentation: "An e-voucher is a digital representation of a specimen...[it] may be ancillary to a classical voucher specimen or it may be the only representative of the specimen in the collection." The goal of the collector should be to document the collection event with all means available. Collection events involving multiple levels of vouchering 
(e.g. morphological, nolecular, digital) will inspire greater confidence and permit a broader array of scientific inquiry by enhancing their evidentiary value.

Digital access and a global genetic resources network. - Maximal use of biomaterials in contemporary research demands sophisticated coordination of collection records married to primary data (molecu'ar biology-based data, digital images, etc.) via electronic and computer technology. Future methods in taxonomy need to be integrated by a transparent, "virtual" organizational schema that provides unity to taxonomy and molecular systematics (Godfray 2002). Currently, avian GRC databases are heterogeneous in structure and organization. However, many more museum coilections will be coming online in the future, and networking them could be facilitated by harmonizing vocabularies and developing standards early on. Coordination of existing collections and information will enhance the value and accessibility of collections (Hoagland 1997, Cambon-Thomsen 2003, Peterson 2005), and awareness of the inventory of tissues available, or lack thereof, may help stimulate needed field collecting. Several preliminary efforts for a common digital framework for GRCs are in the works, such as an initiative from the AOU Committee on Bird Collections currently being organized by Carla Cicero (C. Cicero pers. comm.). Modern bioinformatics initiatives will ultimately link tissue-specimen collection records with bibliographic citations, competing taxonomic determinations, and geospatial referencing information; indeed, some GRCs, such as those at the Museum of Vertebrate Zoology, Berkeley, already have such capabilities in place. The ultimate goal is to develop a national infrastructure capable of supporting research involving genetic resources by promoting the linkage of biological resource collections' online specimen records with the publications and data derived from thcise specimens.

To achieve maximum value, tissue repositories need to be networked with one another and with collections containing voucher specimens (Dessauer et al. 19:38). Such digital networks for voucher collections, such as ORNIS (Ornithological Research .Network Information System), promise an exciting future for those collections. The International Society for Biological and Environmental Repositories (ISBER; see Acknowledgments) provides a forum for such collaboration and communication on advances in tissue collection and preservation protocols, along with current best practices associated with repository management. The Organization for Economic Cooperation and Development's (OECD) Working Party on Biotechnology is calling for a global network of biological resource collections to be established (Organization for Economic Cooperation and Development 2001). The Global Biodiversity Information Facility (GBIF) is similarly calling for the establishment of an international network of biodiversity collections with online databases to provide coordinated electronic access to their catalogues.

Conclusions.-Given the difficulty of procuring funds for collections-based research, the often greater difficulty of obtaining the necessary collecting permits, and, finally, the concomitant destruction of habitats for birds globally, it is not difficult to imagine that collections of organisms made today may well be the last opportunity the scientific community has to obtain archival material for many of the world's species. Continued efforts to secure GR samples from all species, both threatened and common, are justified insofar as each specimen represents a unique record of environmental and evolutionary history (Sheldon and Dittmann 1997, Sheldon 2001). Thankfully, a modern paradigm of preservation that maintains not only the collecting locality and morphological identity of specimens, but also the integrity of the biomolecules within them, is generally accepted. Hopefully, societal acknowledgment of the value of these biomolecules will translate into increased support for GRCs and the museums and other institutions that maintain them.-ScorT $V$. EDwards, Burke Museum of Natural History and Culture, Box 353010, University of Washington, Seattle, Washington 98195, USA (Present address: Department of Ornithology, Museum of Comparative Zoology, Harvard University, 26 Oxford Street, Cambridge, Massachusetts 02138, USA.E-mail: sedwards@fas.harvard.edu); SHAroN BIRKs, Burke Museum of Natural History and Culture, Box 353010, University of Washington, Seattle, Washington 98195, USA; Rовв T. BRUMfield, Museum of Natural Science, Louisiana State University, Baton Rouge, Louisiana 70803, USA; and Robert Hanner, Corriel Institute for Medical Research, 403 Haddon Avenue, Camden, New Jersey 08103, USA. 


\section{AckNowledgments}

We thank the following individuals who provided helpful comments, answered questions about their collections, or provided comments on the manuscript: F. Sheldon, D. Dittmann, C. Cicero, M. Robbins, S. Hackett, N. Rice, M. Peck, M. Braun, P. Sweet, S. Rohwer, R. DeSalle, and $\mathrm{K}$. Winker. The International Society for Biological and Environmental Repositories website is at www.isber.org.

\section{Literature Cited}

Cаmbon-Thomsen, A. 2003. Assessing the impact of biobanks. Nature Genetics 34:25-26.

Couzin, J. 2002. NSF's ark draws alligators, algae, and wasps. Science 297:1638-1639.

Dessauer H. C., C. J. Cole, and M. S. Hafner. 1996. Collection and storage of frozen tissues Pages 29-47 in Molecular Systematics (D. Hillis, C. Moritz, and B. Mable, Eds.). Sinauer Associates, Sunderland, Massachusetts.

Dessauer, H. C., M. S. Hafner, R. M. ZinK, AND C. J. Cole. 1988. A national program to develop, maintain and utilize frozen tissue collections for scientific research. Association of Systematics Collections Newsletter 16:9-10.

Edwards, S. V., W. B. Jennings, and A. M. SHedlock. 2005. Phylogenetics of modern birds in the era of genomics. Proceedings of the Royal Society of London, Series B: in press.

Engstrom, M. D., R. W. Murphy, and O. Haddrath. 1999. Sampling vertebrate collections for molecular research: Practice and policies. Pages 315-330 in Managing the Modern Herbarium: An Interdisciplinary Approach (D. Metsger and S. Byers, Eds.). Elton-Wolf, Vancouver, British Columbia.

Franks, F. 1985. Biophysics and Biochemistry at Low Temperatures. Cambridge University Press, Cambridge, United Kingdom.

Godfray, H. C. J. 2002. Challenges for taxonomy. Nature 417:17-19.

Hoagland, K. E. 1997. Access to specimens and genetic resources: An Association for Systematics Collections position paper. Pages 317-330 in Global Genetic Resources: Access, Ownership, and Intellectual Property Rights (K. E. Hoagland and A. R.
Rossman, Eds.). Association of Systematics Collections, Washington, D.C.

Johnson, N. K., R. M. ZINK, G. F. BarrowClough, AND J. A. Marten. 1984. Suggested techniques for modern avian systematics. Wilson Bulletin 96:543-560.

Miller, H. C., and D. M. Lambert. 2003. An evaluation of methods of blood preservation for RT-PCR from endangered species. Conservation Genetics 4:651-654.

Monk, R. R., AND R. J. Baker. 2001. e-Vouchers and the use of digital imagery in natural history collections. Museology 10:1-8.

Moritz, C., and C. Cicero. 2004. DNA barcoding: Promises and pitfalls. PLoS Biology 2: 1529-1531.

Organization for Economic Cooperation and Development. 2001. Biological Resource Centers: Underpinning the Future of Life Sciences and Biotechnology. [Online.] Available at www.sourceoecd.org.

Peterson, A. T., C. Cicero, and J. Wieczorek. 2005. Free and open access to bird specimen data: Why? Auk 122:987-990.

Prindini, L., R. Hanner, and R. DeSalle. 2002. Obtaining, storing, and archiving specimens for molecular genetic research. Pages 176248 in Methods and Tools in Biosciences and Medicine (MTBM) Techniques in Molecular Systematics and Evolution (R. DeSalle, G. Giribet and W. Wheeler, Eds.). Birkhauser, Basel.

Rocque, D. A., and K. Winker. 2005. Use of bird collections in contaminant and stableisotope studies. Auk 122:990-994.

Ruedas, L. A., J. Salazar-Bravo, J. W. Dragoo, AND T. L. Yates. 2000. The importance of being earnest: What, if anything, constitutes a "specimen examined"? Molecular Phylogenetics and Evolution 17:129-132.

Seutin, G., B. N. White, and P. T. Boag. 1991. Preservation of avian blood and tissue samples for DNA analysis. Canadian Journal of Zoology 69:82-90.

Sheldon, F. H. 2001. Molecular collections for basic research: Museums, methods, and morality. Pages 331-346 in Proceedings of the International Conference on $\mathrm{In}$-situ and Ex-situ Biodiversity Conservation in the New Millenium (Z. Yaacob, S. Moo-Tan, and S. Yorath, Eds.). Yayasan Sabah, Kota Kinabalu, Sabah.

Sheldon, F. H., and D. L. Dittmann. 1997. The 
value of vertebrate tissue collections in applied and basic science. Pages 151-162 in Global Genetic Resources: Access, Ownership, and Intellectual Property Rights (K. E. Hoagland and A. R. Rossman, Eds.). Association of Systematics Collections, Washington, D.C.

Stoeckle, M. 2003. Taxonomy, DNA, and the bar code of life. Bioscience 53:796-797.

Thомаs, R. H. 1994. Molecules, museums and vouchers. Trends in Ecology and Evolution 9:413-414.

WANG, Z., G. E. Hill, A. J. Baker, and S. V. EDWARDS. 2003. Keconciling actual and inferred population histories in the House Finch (Carpodacus mexicanus) by AFLP analysis. Evolution 57:2852-2864.

Winker, K., M. J. Braun, and G. R. Graves. 1996. Voucher specimens and quality control in avian molecular studies. Ibis 138:345-346.

The Auk 122(3):984-987, 20105

(C) The American Ornithologists' Union, 2005. Printed in USA.

New Directions for Bioacoustics Collections.-Bioacoustics collections contain recordings of sounds produced by animals. The technology that made possible the capture of ephemeral sound events appeared more than 100 years ago (Koch 1955). However, for biologists who sought to record animal sounds in the field, technological innovation:s in truly portable sound equipment and reliable media emerged only after World War II. Nevertheless, before the introduction of the portable magnetic tape recorder, pioneers at Cornell University experimented with recording sound on motion picture film (Brand 1935). A recording field-trip required a truckload of equipment, and it took weeks to get the film developed. But these were successes with this cumbersome technology, including the only known recording of the Ivory-billed Woodpecker (Campephilus principalis), made in 1935 by the Cornell expedition to Louisiana (Kellogg 1962). Biologists who rediscovered the Ivory-billed Woodpecker in Arkansas in 2004 were trained to listen for the bird with this recording, and it is crucial to researchers in the Bioacoustics Research Program at Cornell in evaluating more than 17,000 hours of automated recordings made to detect calling individuals since December 2004.
A specimen in a bioacoustics collection is a recording of one target animal or group of animals and the associated metadata. The sounds produced by the animal(s) are usually recorded in one session for a variable length of time (seconds, more often minutes, or even days, as technological advances improved storage capacity). Specimens are obtained on master field recordings that may contain multiple specimens and multiple species from multiple locations. A "label" for an acoustic specimen, separating it from other specimens on a master tape (or other media), is the narration by the recordist (Kroodsma et al. 1996). In the era of reel-to-reel tape, specimens were cut out of the master tape. Thus, specimens in bioacoustics collections are termed "recordings" or "cuts." More recently, especially with the advent of analog cassettes, cuts were duplicated from the master field recordings, preserving the integrity of the master field tape.

A white leader tape was added to each specimen obtained from the master field tape. This leader served as a visible label onto which was written information about species, location, and date. The specimen was then spliced onto a tape reel containing cuts from the same species. This species reel organization simplified retrieval of specimens and until very recently was the way all major sound collections maintained their sound specimens. The three major collections, listed in alphabetical order, are (1) Borror Laboratory of Bioacoustics (BLB), The Ohio State University (blb.biosci.ohio-state.edu); (2) Macaulay Library (ML), Laboratory of Ornithology, Cornell University (birds.cornell.edu/lns); and (3) National Sound Archive (NSA), Wildlife Division, The British Library (www.bl.uk/nsa). Other important collections include (and see Kettle 1989): Bioacoustics Laboratory and Archive (BLA), Florida State Museum; Center for Sound Communication, Odense University, Denmark; Sound Library, The Australian National Wildlife Collection; and Library of Wildlife Sounds, Museum of Vertebrate Zoology, University of California.

Analog magnetic tape, depending on the formulation, has a life expectancy of $10-40$ years and degrades with each use through magnetic particle loss. Thus, analog tape collections started in the late 1940s were recently faced with loss if not duplicated. Duplication to new analog tape stock has the same limitations, is labor-intensive, and is becoming costly as digital media erodes 
Copyright of Auk is the property of American Ornithologists Union. The copyright in an individual article may be maintained by the author in certain cases. Content may not be copied or emailed to multiple sites or posted to a listserv without the copyright holder's express written permission. However, users may print, download, or email articles for individual use. 